\title{
molecules
}

ISSN 1420-3049

www.mdpi.com/journal/molecules

Article

\section{A Benzoic Acid Derivative and Flavokawains from Piper species as Schistosomiasis Vector Controls}

Ludmila N. Rapado ${ }^{1,2, *}$, Giovana C. Freitas ${ }^{3}$, Adriano Polpo ${ }^{4}$, Maritza Rojas-Cardozo ${ }^{5}$, Javier V. Rincón ${ }^{5}$, Marcus T. Scotti ${ }^{6}$, Massuo J. Kato ${ }^{3}$, Eliana Nakano ${ }^{1, \dagger}$ and

Lydia F. Yamaguchi ${ }^{3, \dagger, *}$

1 Laboratório de Parasitologia, Instituto Butantan, Av. Vital Brasil, 1500, São Paulo, SP, CEP 05503-900, Brazil; E-Mail: eliananakano@butantan.gov.br

2 Instituto de Ciências Biomédicas, Universidade de São Paulo, Av. Prof. Lineu Prestes, 1374, São Paulo, SP, CEP 05508-000, Brazil

3 Research Support Center in Diversity of Natural Products, Instituto de Química, Universidade de São Paulo, Av. Prof. Lineu Prestes, 748, sala 1124, São Paulo, SP, CEP 05508-000, Brazil; E-Mails: giovanacf@gmail.com (G.C.F.); majokato@iq.usp.br (M.J.K.)

4 Departamento de Estatística, Centro de Ciências Exatas e de Tecnologia, Universidade Federal de São Carlos, Via Washington Luís, km 235, Sao Carlos, SP, Caixa-postal 676, CEP 13565-905, Brazil; E-Mail: polpo@ufscar.br

5 Department of Pharmacy, Faculty of Sciences, Universidad Nacional de Colombia, Kr 30 45-03, Bogotá, Colombia; E-Mails: marojasc@unal.edu.co (M.R.-C.); jrinconv@unal.edu.co (J.V.R.)

6 Centro de Ciências Aplicadas e Educação, Universidade Federal da Paraíba, Campus IV, Rua da Mangueira, s/n, Rio Tinto, PB, CEP 5829-7000, Brazil; E-Mail:mtscotti@gmail.com

$\dagger$ These authors contributed equally to the organization of this article.

* Authors to whom correspondence should be addressed; E-Mails: ludmilanr@usp.br (L.N.R.); lydyama@iq.usp.br (L.F.Y.); Tel.: +55-11-3091-7335 (L.N.R.); +55-11-3091-3813 (L.F.Y.).

Received: 11 March 2014; in revised form: 11 April 2014 / Accepted: 15 April 2014 /

Published: 23 April 2014

\begin{abstract}
The search of alternative compounds to control tropical diseases such as schistosomiasis has pointed to secondary metabolites derived from natural sources. Piper species are candidates in strategies to control the transmission of schistosomiasis due to their production of molluscicidal compounds. A new benzoic acid derivative and three flavokawains from Piper diospyrifolium, P. cumanense and P. gaudichaudianum displayed significant activities against Biomphalaria glabrata snails. Additionally, "in silico" studies
\end{abstract}


were performed using docking assays and Molecular Interaction Fields to evaluate the physical-chemical differences among the compounds in order to characterize the observed activities of the test compounds against Biomphalaria glabrata snails.

Keywords: schistosomiasis; molluscicide; benzoic acid; flavokawain; Piper

\section{Introduction}

Parasitic diseases are a major public health problem, especially in the developing countries. Schistosomiasis is considered by the World Health Organization (WHO) to be the second most relevant tropical disease [1]. The prevalence of this malady results primarily from a lack of basic sanitation. Human schistosomiasis transmission begins with the penetration of the skin by larval cercariae living in fresh water. Subsequently, the parasite continues development in multiple human organs [2,3]. Progressive efforts have been made to eradicate the disease, and one of the key strategies to control of the intermediate host, snails of the Biomphalaria genus, which act as a transmission vector of cercariae [4]. Currently, a commercially available niclosamide-based molluscicide, Bayluscide ${ }^{\circledR}$ (Bayer) is the most effective compound employed in schistosomiasis control programs [5]. However, there are several negative aspects of Bayluscide ${ }^{\circledR}$ use, including compound resistance and toxicity to other organisms [6].

The continued importance of natural products as a source of new lead compounds has led to the search for molluscicidal compounds in the plethora of plants found in tropical forests [7]. The effective molluscicidal activity of crude extracts derived from the Piper species supported further investigation of alternative compounds to control snail populations [8]. Piper diospyrifolium crude leaf extract demonstrated high activity against Biomphalaria glabrata. Thus, the phytochemical study of leaf extract resulted in the isolation and structural determination of a new active benzoic acid derivative. Additionally, flavokawain A was isolated from crude leaf extracts and its activity was compared to 2',4',6'-trihydroxydihydrochalcone and dihydroflavokawain $\mathrm{C}$ isolated from $P$. cumanense and $P$. gaudichaudianum, respectively. A comparison of benzoic acid derivative activity was made with commercially available analogs, hydroquinone and $p$-hydroxybenzoic acid.

Additionally, "in silico" studies were performed by docking analysis using a RXR-like protein (retinoid X receptor) as a potential drug target for $B$. glabrata. RXR-like proteins belong to the nuclear receptor (NR) protein family, a superfamily of transcription factors present in metazoans [9], which regulate various biological processes including cell growth, development and metamorphosis [9]. The capacity of these nuclear receptors to bind small molecules might be used to control several biological processes $[9,10]$. The receptor-mediated effects are stimulated and/or inhibited by endogenous cognate ligands specific for each NR, but also by exogenous substances including natural products and synthetic chemicals. Considering these promising pharmacological targets, NRs and their ligands have attracted scientific interest, particularly for drug discovery and in toxicology and environmental science $[10,11]$. 
Molecular interaction fields were also employed to characterize the similarity and physical-chemical differences among the test compounds in order to explain the differences in activity profiles against B. glabrata [12].

\section{Results and Discussion}

\subsection{Compound Purification}

Fractionation of $P$. diospyrifolium leaf extracts was performed using flash purification leading to the isolation of flavokawain A $\mathbf{1}$ and the new benzoic acid derivative 2. Purified compound $\mathbf{1}$ was obtained as yellow crystals. The molecular mass was determined as $\mathrm{C}_{18} \mathrm{H}_{18} \mathrm{O}_{5}$, based on HRESIMS data which displayed an $[\mathrm{M}+\mathrm{H}]^{+}$quasi-molecular ion peak at $m / z 315.1231$ (calculated for $\mathrm{C}_{18} \mathrm{H}_{18} \mathrm{O}_{5}$ $\left.[\mathrm{M}+\mathrm{H}]^{+}=315.1227\right)$. Comparison of its spectral data with literature values identified compound $\mathbf{1}$ as flavokawain A [13].

Compound 2 was a dark yellow solid. The HRESIMS analysis indicated the presence of a quasi-molecular ion peak at $\mathrm{m} / z$ 357.2060, corresponding to the formula $\mathrm{C}_{22} \mathrm{H}_{28} \mathrm{O}_{4}$ (calculated for $\mathrm{C}_{22} \mathrm{H}_{28} \mathrm{O}_{4}[\mathrm{M}+\mathrm{H}]^{+}=357.2060$ ). The ${ }^{1} \mathrm{H}-\mathrm{NMR}$ spectral data (Table 1) indicated the presence of one 1,3,4-trisubstituted aromatic ring according to the signals at $\delta 8.59(\mathrm{~d}, J=2.0), 7.03(\mathrm{~d}, J=10.0)$ and $8.16(\mathrm{dd}, J=10.0,2.0$ ) assigned to $\mathrm{H} 2, \mathrm{H} 5$ and H6, respectively (Table 1). Singlet signals at $\delta 1.65$ $(3 \mathrm{H}), 2.26(3 \mathrm{H}), 1.65(3 \mathrm{H})$ and $1.57(3 \mathrm{H})$ were assigned to methyl groups linked to $\mathrm{sp}^{2}$ carbon atoms. The farnesyl side chain was determined through the association of these methyl groups with triplet signals at $\delta 6.87,5.17$ and 5.09 of the olefinic hydrogens.

The ${ }^{13} \mathrm{C}$-NMR spectral data indicated the presence of one carboxyl group of a benzoic acid at $\delta$ 170.90. In addition, six aromatic carbon signals were detected in the range of $\delta 119$ to 168, assigned the 3-alkyl-4-hydroxybenzoic acid moiety. The remaining signals were attributed to a farnesyl moiety with six of them $\delta 118.80,164.10,127.70,136.82,124.30$ and 131.57 corresponding to three double bonds, $\delta 42.11,26.81,39.79,26.30$ were assigned to methylene groups and $\delta 25.91,20.57,16.28$ and 17.80 to methyl groups of the farnesyl group (Table 1). A comparison of data in the literature [14] with that of compound 2 corroborated the structure this compound as 4-hydroxy-3-(3,7,11-trimethyldodeca2,5,10-trienyl)benzoic acid (Figure 1).

Compound 3, a yellow crystalline substance, was isolated from $P$. cumanense leaves after extensive purification steps based on silica gel chromatography. The HRESIMS data determined its molecular formula to be as $\mathrm{C}_{15} \mathrm{H}_{14} \mathrm{O}_{4}\left(\mathrm{~m} / \mathrm{z}: 259.0980[\mathrm{M}+\mathrm{H}]^{+}\right.$obtained, calculated $[\mathrm{M}+\mathrm{H}]^{+}=$ 259.0970). Comparison of NMR data with the literature identified this compound as 2',4',6'trihydroxydihydrochalcone [15].

Compound 4 was isolated from leaves of $P$. gaudichaudianum and had a quasi-molecular ion peak at $m / z: 303.1236[\mathrm{M}+\mathrm{H}]^{+}$assigned to the formula $\mathrm{C}_{17} \mathrm{H}_{18} \mathrm{O}_{5}$, based on HRESIMS data (calculated for $\mathrm{C}_{17} \mathrm{H}_{18} \mathrm{O}_{5}[\mathrm{M}+\mathrm{H}]^{+}=303.1232$ ). NMR data and literature comparison identified this compound as dihydroflavokawain $\mathrm{C}[16]$. 
Table 1. ${ }^{1} \mathrm{H}(200 \mathrm{MHz})$ and ${ }^{13} \mathrm{C}(50 \mathrm{MHz})$ NMR data of compound 2.

\begin{tabular}{ccc}
\hline & Compound 2 & \\
\hline Position & ${ }^{\mathbf{1}} \mathbf{H}(\boldsymbol{J} \mathbf{H z})$ & 120.31 \\
\hline 1 & & 133.16 \\
2 & $8.59(1 \mathrm{H}, \mathrm{d}, 2.0)$ & 119.70 \\
3 & & 167.90 \\
4 & & 119.01 \\
5 & $7.03(1 \mathrm{H}, \mathrm{d}, 10.0)$ & 137.17 \\
6 & $8.16(1 \mathrm{H}, \mathrm{dd}, 10.0,2.0)$ & 195.63 \\
$1^{\prime}$ & & 118.80 \\
$2^{\prime}$ & $6.87(1 \mathrm{H}, \mathrm{s})$ & 164.10 \\
$3^{\prime}$ & & 42.11 \\
$4^{\prime}$ & $2.37(2 \mathrm{H}, \mathrm{m})$ & 26.81 \\
$5^{\prime}$ & $2.04(2 \mathrm{H}, \mathrm{m})$ & 127.70 \\
$6^{\prime}$ & $5.17(1 \mathrm{H}, \mathrm{m})$ & 136.82 \\
$7^{\prime}$ & & 39.79 \\
$8^{\prime}$ & $2.37(2 \mathrm{H}, \mathrm{m})$ & 26.30 \\
$9^{\prime}$ & $2.04(2 \mathrm{H}, \mathrm{m})$ & 124.30 \\
$1^{\prime}$ & $5.09(1 \mathrm{H}, \mathrm{m})$ & 131.57 \\
$1^{\prime}$ & & 25.91 \\
$1^{\prime}$ & $1.65(3 \mathrm{H}, \mathrm{s})$ & 20.57 \\
$1^{\prime}$ & $2.26(3 \mathrm{H}, \mathrm{s})$ & 16.28 \\
$1^{\prime}$ & $1.65(3 \mathrm{H}, \mathrm{s})$ & 17.80 \\
$1^{\prime}$ & $1.57(3 \mathrm{H}, \mathrm{s})$ & 170.90 \\
COOH $^{\prime}$ & $13.49(1 \mathrm{H}, \mathrm{s})$ & \\
\hline & & \\
\hline
\end{tabular}

Figure 1. Chemical structures of the compounds assessed in this study.<smiles>COc1ccc(/C=C/C(=O)c2c(O)cc(OC)cc2OC)cc1</smiles><smiles>CC(C)=CCCC(C)=CCCC(C)=CC(=O)c1cc(C(=O)O)ccc1O</smiles><smiles>O=C(CCc1ccccc1)c1c(O)cc(O)cc1O</smiles><smiles>COc1cc(O)c(C(=O)CCc2ccc(O)cc2)c(OC)c1</smiles><smiles>O=C(O)c1ccc(O)cc1</smiles><smiles>Oc1ccc(O)cc1</smiles> 


\subsection{Molluscicidal and Ovicidal Activities}

The molluscicidal and ovicidal activities of compounds $\mathbf{1}$ and $\mathbf{2}$ were evaluated against B. glabrata. The molluscicidal and ovicidal activities of commercially available analogs of the benzoic acid derivative, hydroquinone and $p$-hydroxybenzoic acid, and the two chalcones $\mathbf{3}$ and $\mathbf{4}$ isolated from P. cumanense and P. gaudichaudianum, were also evaluated (Table 2, Supplementary Table S1). Compound 2 was potent against adult snails among the natural products tested $\left(\mathrm{LC}_{50} 7.28 \mu \mathrm{g} / \mathrm{mL}\right)$ (Table 2). A concentration of $12 \mu \mathrm{g} / \mathrm{mL}$ resulted in $100 \%$ dead animals after $24 \mathrm{~h}$ of exposure (Supplementary Table S1). This benzoic acid derivative was significantly more potent compared with $p$-hydroxybenzoic acid $\left(\mathrm{LC}_{50} 1302.91 \mu \mathrm{g} / \mathrm{mL}\right)$. The $\mathrm{C}_{15}$ isoprenoid side chain of 2 that confers lipophilicity to the compound can attach or insert in the mollusk membrane and may explain this difference in activity. Overall, a simple quinone 6 was the most active $\left(\mathrm{LC}_{50} 3.15 \mu \mathrm{g} / \mathrm{mL}\right)$ among the tested compounds. The quinone was also active against the embryonic stages of $B$. glabrata, however, the benzoic acid and compound $\mathbf{1}$ did not have any activity against these stages (Table 2) (Supplementary Table S1). A concentration of $9 \mu \mathrm{g} / \mathrm{mL}$ hydroquinone resulted in $100 \%$ dead adult animals after $24 \mathrm{~h}$ of exposure. In the embryonic stages, the blastula and gastrula stages were more sensitive than the trocophore and veliger stages with $100 \%$ dead animals after $24 \mathrm{~h}$ using 2, 4, 8 and $8 \mu \mathrm{g} / \mathrm{mL}$ hydroquinone, respectively.

Table 2. $\mathrm{LC}_{50}$ and $\mathrm{LC}_{90}(\mu \mathrm{g} / \mathrm{mL})$ for B. glabrata in different developmental stages exposed to isolated compounds.

\begin{tabular}{|c|c|c|c|c|c|c|}
\hline \multirow{2}{*}{ Compounds } & & \multirow{2}{*}{ Adults } & \multicolumn{4}{|c|}{ Developmental stages } \\
\hline & & & Blastula & Gastula & Trocophore & Veliger \\
\hline \multirow{2}{*}{ Flavokawain A (1) } & $\mathbf{L C}_{50}$ & $\begin{array}{c}21.85 \\
{[19.22-24.21]}\end{array}$ & $\mathrm{nc}$ & $\mathrm{nc}$ & nc & $\mathrm{nc}$ \\
\hline & $\mathbf{L C}_{90}$ & $\begin{array}{c}27.97 \\
{[27.97-33.95]}\end{array}$ & nc & nc & $\mathrm{nc}$ & nc \\
\hline \multirow{2}{*}{$\begin{array}{c}\text { 4-Hydroxy-3- } \\
(3,7,11- \\
\text { trimethyldodeca- } \\
2,5,10 \text {-trienyl) } \\
\text { benzoic acid (2) }\end{array}$} & $\mathbf{L C}_{50}$ & $\begin{array}{c}7.28 \\
{[6.54-7.96]}\end{array}$ & $\mathrm{nc}$ & $\mathrm{nc}$ & nc & nc \\
\hline & $\mathbf{L C}_{\mathbf{9 0}}$ & $\begin{array}{c}10.04 \\
{[10.04-11.76]}\end{array}$ & nc & nc & nc & nc \\
\hline \multirow{2}{*}{$\begin{array}{l}\text { 2',4',6'-Trihydroxy- } \\
\text { dihydrochalcone (3) }\end{array}$} & $\mathbf{L C}_{50}$ & $\begin{array}{c}5.35 \\
{[4.28-6.30]}\end{array}$ & $\begin{array}{c}10.18 \\
{[9.68-10.69]}\end{array}$ & $\begin{array}{c}10.31 \\
{[9.86-10.79]}\end{array}$ & $\begin{array}{c}10.71 \\
{[10.24-11.16]}\end{array}$ & $\begin{array}{c}11.83 \\
{[11.35-12.31]}\end{array}$ \\
\hline & $\mathbf{L C}_{90}$ & $\begin{array}{c}6.47 \\
{[6.47-9.06]}\end{array}$ & $\begin{array}{c}14.12 \\
{[14.12-15.90]}\end{array}$ & $\begin{array}{c}13.54 \\
{[13.54-15.28]}\end{array}$ & $\begin{array}{c}14.44 \\
{[14.44-16.23]}\end{array}$ & $\begin{array}{c}14.87 \\
{[14.87-16.19]}\end{array}$ \\
\hline \multirow{4}{*}{$\begin{array}{l}\text { Dihydroflavokawain } \\
\text { C (4) } \\
\text { p-Hydroxybenzoic } \\
\text { acid (5) }\end{array}$} & $\mathbf{L C}_{50}$ & $\mathrm{nc}$ & $\mathrm{nc}$ & $\mathrm{nc}$ & nc & $\mathrm{nc}$ \\
\hline & $\mathbf{L C}_{90}$ & nc & nc & $\mathrm{nc}$ & nc & $\mathrm{nc}$ \\
\hline & $\mathbf{L C}_{50}$ & nc & $\mathrm{nc}$ & nc & nc & nc \\
\hline & $\mathbf{L C}_{90}$ & $\mathrm{nc}$ & $\mathrm{nc}$ & $\mathrm{nc}$ & $\mathrm{nc}$ & nc \\
\hline \multirow{2}{*}{ Hydroquinone (6) } & $\mathbf{L C}_{\mathbf{5 0}}$ & $\begin{array}{c}3.12 \\
{[2.70-3.59]}\end{array}$ & $\begin{array}{c}1.17 \\
{[1.14-1.20]}\end{array}$ & $\begin{array}{c}1.98 \\
{[1.92-2.04]}\end{array}$ & $\begin{array}{c}2.74 \\
{[2.60-2.89]}\end{array}$ & $\begin{array}{c}4.26 \\
{[4.12-4.41]}\end{array}$ \\
\hline & $\mathrm{LC}_{90}$ & $\begin{array}{c}5.27 \\
{[5.27-6.97]}\end{array}$ & $\begin{array}{c}1.51 \\
{[1.51-1.59]}\end{array}$ & $\begin{array}{c}2.86 \\
{[2.86-3.05]}\end{array}$ & $\begin{array}{c}5.83 \\
{[5.83-6.45]}\end{array}$ & $\begin{array}{c}6.17 \\
{[6.17-6.54]}\end{array}$ \\
\hline
\end{tabular}

$\mathrm{nc}=$ not calculated. [ ] 95\% confidence interval. $n=30$ snails for the adult stage. Values were obtained at the end of the 7 th day of observation. 
Three compounds with chalcone skeleton, 1, 3 and 4, were tested against B. glabrata. Flavokawain A (1) showed moderate molluscicidal activity $\left(\mathrm{LC}_{50} 21.85 \mu \mathrm{g} / \mathrm{mL}\right)$ and did not exhibit any activity in the embryogenic stages of the snail. Dihydroflavokawain C (4) did not exhibit any activity at any of the life stages of the snail. The compound with the most potent activity was 2',4',6'-trihydroxydihydrochalcone (3), which was active against all life stages of the snail. This compound was more active in the adults ( $\mathrm{LC}_{50} 5.35 \mu \mathrm{g} / \mathrm{mL}$ ) (Table 2, Supplementary Table S1), but in the embryonic stages caused a delay in development; after 7 days all the embryos had not completed development and remained in the eggs. The eggs were examined daily and regardless of heart beat detection did not emerge from the eggs. All of the embryos were deceased after 16 days.

Considering that RXR-like protein can regulate biological processes in B. glabrata, theoretical studies were performed, comparing the activity of the compounds and their binding energies in the active site looking for an antagonist compound for this protein. In-silico docking analysis determined that all of the compounds interact with the RXR-like protein at arginine 290 through hydrogen bonding (compounds 1, 3, 4 and $\mathbf{6}$ ) or by electrostatic interaction in the benzoic acid derivatives (compounds 2 and $\mathbf{5}$ ) in the same manner as the carboxyl group of retinoic acid (Figure 2).

Figure 2. Best docking results showing electrostatic (green), hydrogen bonds (blue) and hydrophobic (red) interactions between the ligands and active site of RXR-protein like of Biomphalaria glabrata (PDB code: 1XIU).

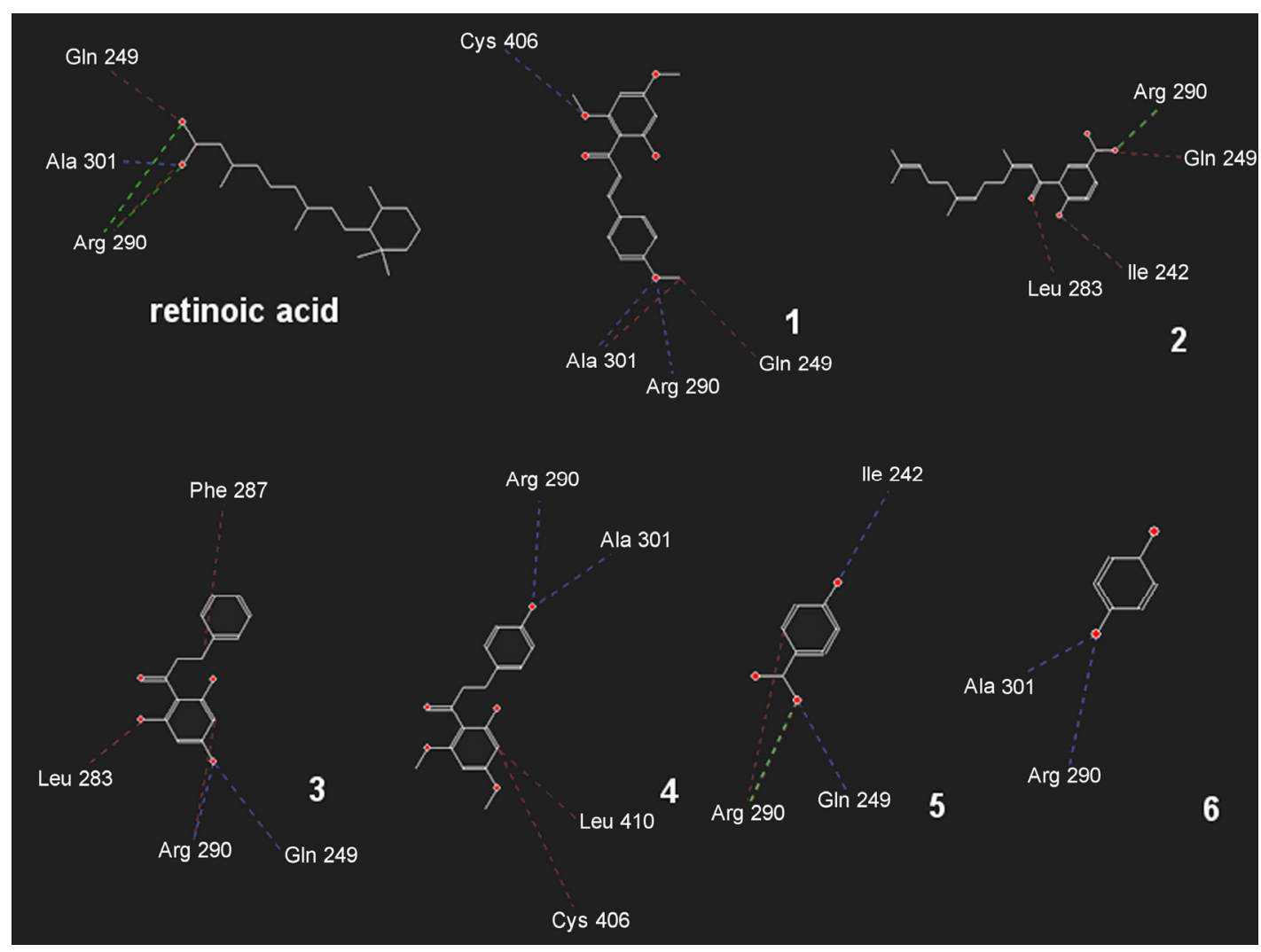

The analysis of the hydrophobic surface of the binding pocket site of the enzyme (Supplementary Figure S1) revealed that only small lipophilic compounds might bind in this site. Considering these observations, compound $\mathbf{2}$ and retinoic acid, each having a carboxyl group and a lipophilic side chain, are able to form electrostatic interactions with arginine 290 of the enzyme and insert the rest of the 
chain in to the hydrophobic region of the binding pocket. Compound $\mathbf{5}$ forms the same electrostatic interaction of compound 2 with arginine 290 and forms hydrogen bonds with glutamine 249 and isoleucine 242. Additionally, compound 3 forms hydrogen bonds with both residues. Compounds 1, 4 and 6, similarly to retinoic acid, form hydrogen bonds with arginine 290 and alanine 301 in the binding pocket site (Figure 2).

A PCA analysis was performed using the descriptors generated by the Molecular Interaction Fields (MIF) describing the similarity/dissimilarity of compound interactions with the lipophilic, water, hydrogen acceptor and hydrogen donor probes that represent the same interactions as the biological environment that these compounds were subjected to during the assay. The scores plot of PC1 and PC2 is presented in Figure 3 that explains $34.5 \%$ and $24.9 \%$ of the total observed variance. The loadings plot showed that lipophilic capacity factors descriptors ( $\mathrm{CD}$-hydrophobic volume per surface unit) and $\mathrm{D}$ descriptors (hydrophobic volumes generated by the lipophilic fields) were on the right side (positive contribution to PC1). Retinoic acid and compound $\mathbf{2}$ are located in the first quadrant, in the same position as the descriptors IW (Integy moment) and WN (Hydrogen bond acceptor volumes), which first encodes the unbalance between the center of mass of a molecule and the barycenter of its hydrophilic regions and second encodes the hydrogen bonding ligand acceptor fields, that contribute positively to PC1 and PC2 (Supplementary Figures S1 and S2). Compound 3, located in the second quadrant, displays well-defined polar and lipophilic regions (Supplementary Figure S2). Compounds 5 and 6 were the smallest and more hydrophilic compounds and are located in the second and third quadrants, respectively. Their presence in these positions may be explained by the presence of descriptors CW (hydrophilic capacity factors/hydrophilic volume per surface unit) that confers a negative contribution to $\mathrm{PC} 1$, which represents the hydrophilic volume per surface unit of the molecule (Figure 3 and Supplementary Figure S2) [14]. Comparing compounds 1 and 4, that are located in the fourth quadrant of the score plot, where DD (differences of the hydrophobic volumes) descriptors are common to both and encode the variation of hydrophobic volumes according the three dimensional conformation of the less active ligands [14].

GRID descriptors generated by MIF were evaluated to elucidate some of the similarities and dissimilarities between the compounds in order to characterize intermolecular interactions. The docking results showed that all compounds could interact in the same binding pocket as retinoic acid and the distribution of hydrophilic and hydrophobic regions corroborate with the analysis of the Volsurf approach.

The pattern obtained in PCA permitted to identify the physical-chemical features of the tested compounds, such as the hydroxybenzoic acid or hydroxylated phenyl fragments (hydrophilic regions) with lipophilic chains (alkyl or aromatic), which were responsible for higher activity of compounds 2 and $\mathbf{3}$, and consequently, accounted for the lower activity of compounds $\mathbf{1}$ and $\mathbf{4}$ which are abundant in hydrophilic regions. These structural features may be used as a guide for further synthetic optimization or to select new structures with potential activity. However, the physical-chemical differences of compounds 5, 3 and $\mathbf{6}$ are not so simple to interpret to explain their activity and the inactivity of $p$-hydroxybenzoic acid. 
Figure 3. Scores (a) and loadings plot (b) of PCA generated using 57 descriptors generated by molecular interaction fields for probes water, amide nitrogen, carboxylic oxygen and DRY (lipophilic).

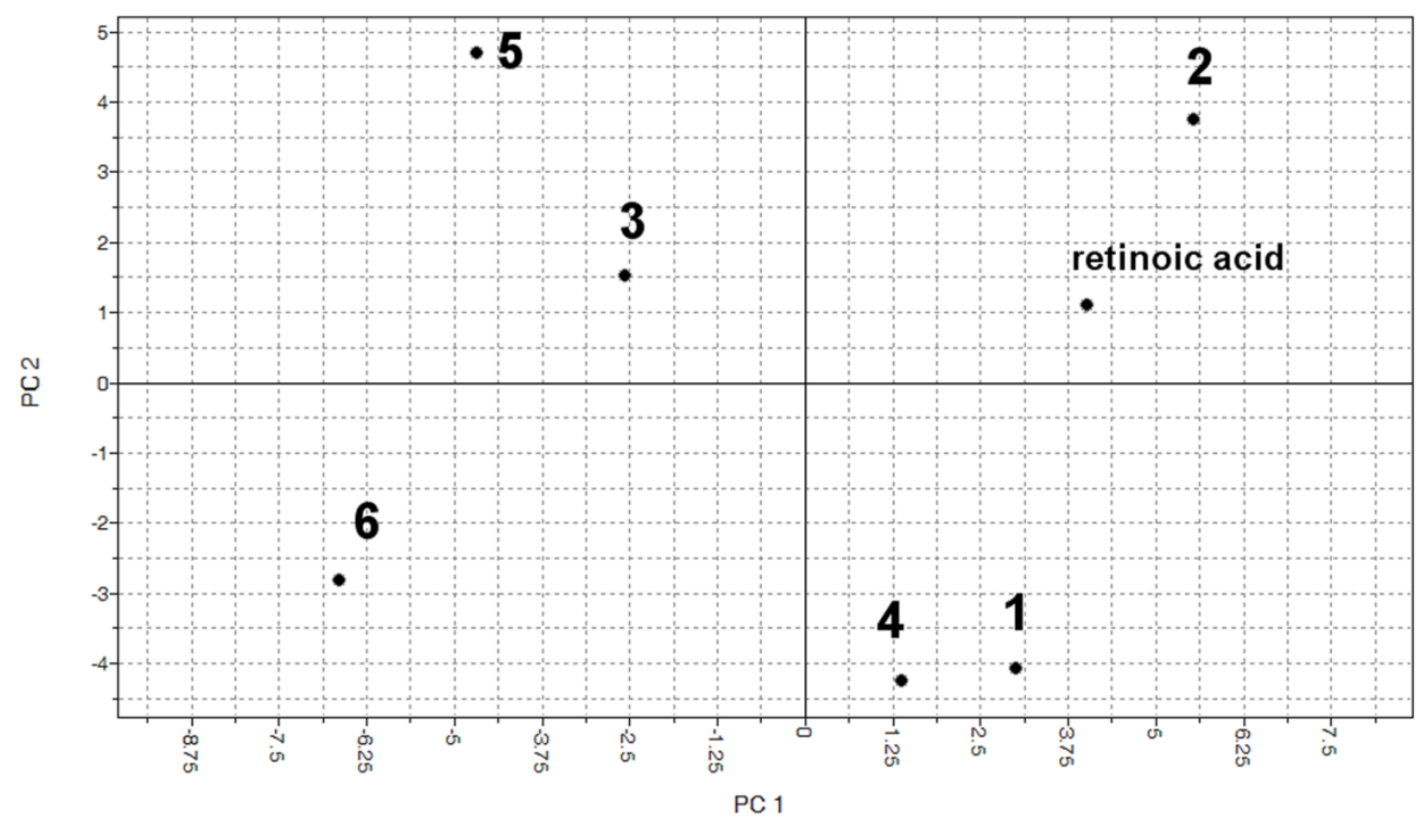

(a)

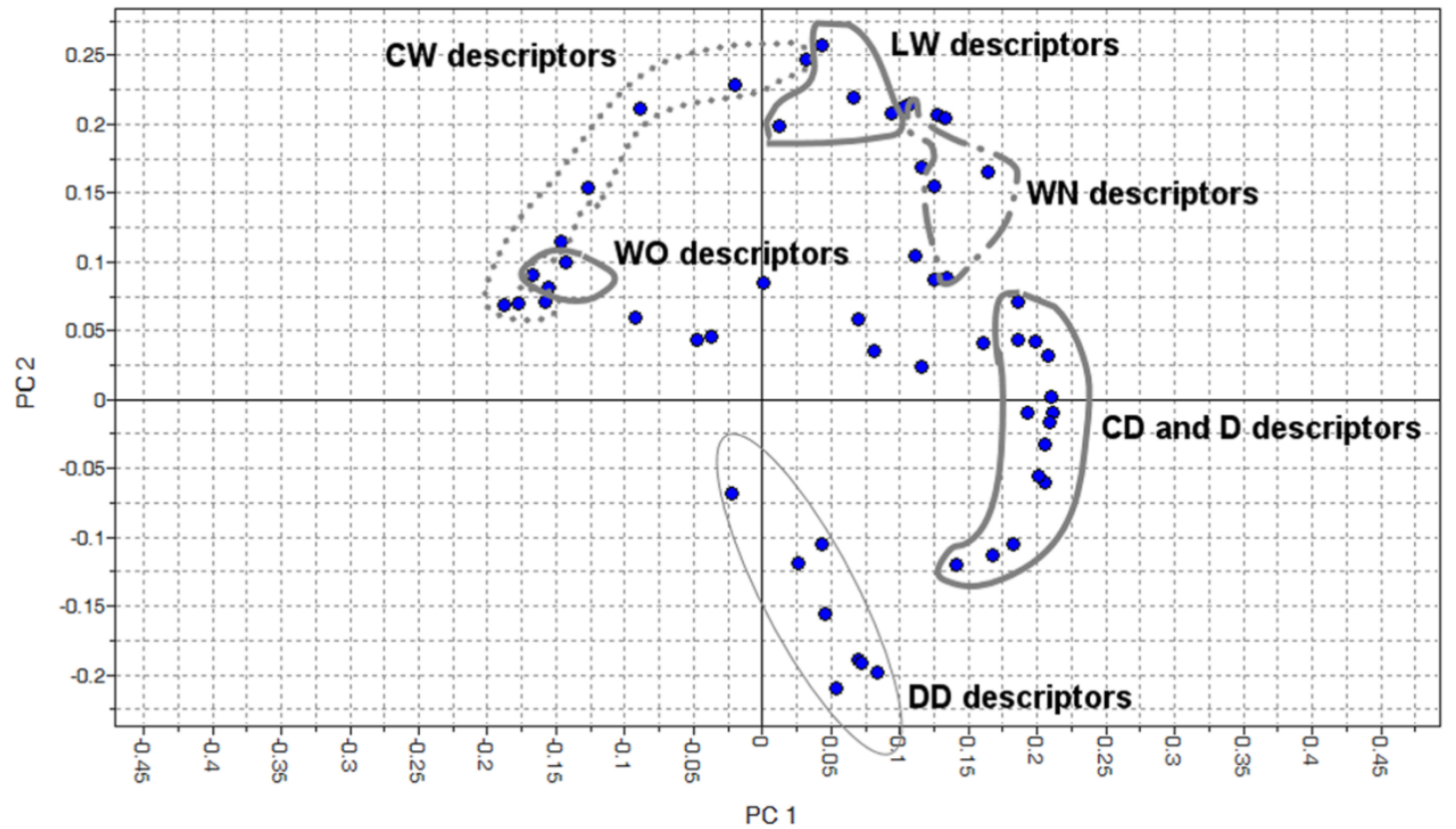

(b)

\section{Experimental Section}

\subsection{General}

The ${ }^{1} \mathrm{H}$ and ${ }^{13} \mathrm{C}-\mathrm{NMR}$ were recorded on a Bruker DRX500 (Billerica, MA, USA) spectrometer (200 MHz for ${ }^{1} \mathrm{H}$ and $50 \mathrm{MHz}$ for ${ }^{13} \mathrm{C}$ ) in $\mathrm{CDCl}_{3}$ using TMS as internal standard. HREIMS analysis was recorded on Bruker MicrOTOFQ-II (Bremen, Germany). HPLC analyses were performed in a Shimadzu (Kyoto, Japan) system with binary pumps LC-20 AD equipped with a UV detector SPD-20 
A, column oven CTO 20A, control unit CBM20A, LCSolution for chromatogram manipulation and Phenomenex Luna $2.5 \mu \mathrm{m}$ C18(2)-HST, $100 \times 2 \mathrm{~mm}$ (Torrance, CA, USA), column. The mobile phase consisted of acetonitrile:water ( $0.1 \%$ formic acid) and flow rate of $0.2 \mathrm{~mL} / \mathrm{min}$. The column purification was performed using Biotage Flash (IsoleraOne) system (Uppsala, Sweden). The binary mobile phase consisted of hexane and acetyl acetate, the flow rate was kept in $12 \mathrm{~mL} / \mathrm{min}$ for a total run time of $7 \mathrm{~min}$. The system was run in a gradient mode: eight volumes of $17 \mathrm{~mL}$ of mobile phase (6\% of ethyl acetate and $94 \%$ of hexane) and three volumes of $17 \mathrm{~mL}(26 \%$ of ethyl acetate and $74 \%$ of hexane). The peaks were monitored at 280 and $254 \mathrm{~nm}$ and the collected fractions were analyzed by HPLC.

\subsection{Plant Material}

Piper diospyrifolium Kunth. and P. gaudichaudianum Kunth. were collected in the garden of Chemistry Institute, University of São Paulo, Brazil. The voucher specimens K-431 and K-031 were deposited in the Herbarium at Instituto de Pesquisas Jardim Botânico do Rio de Janeiro and Prof. Elsie Franklin Guimarães from the same Institute identified the species. Piper cumanense H.B.K. was collected in Zapatoca, province of Santander, Colombia and identified by Prof. Ricardo Callejas (Universidad de Antioquia, Colombia). The voucher specimen (COL 468660) was deposited at the Herbarium of Universidad Nacional de Colombia.

\subsection{Extraction and Isolation}

Leaves of $P$. diospyrifolium $(250 \mathrm{~g})$ and $P$. gaudichaudianum $(100 \mathrm{~g})$ were dried in a $40{ }^{\circ} \mathrm{C}$ oven, milled and extracted $3 \times$ with $\mathrm{MeOH}(1 \mathrm{~L})$ at room temperature. The extracts were filtered, and the organic phase was evaporated using a rotary evaporator. The crude extract (33 g, P. diospyrifolium; $18 \mathrm{~g}$, P. gaudichaudianum) were dissolved in $10 \%$ of water in $\mathrm{MeOH}$ and filtered through Celite ${ }^{\circledR}$ (Merck, Whitehouse Station, NJ, USA) and extracted with EtOAc, yielding $10 \mathrm{~g}$ and $6 \mathrm{~g}$ of organic fractions, respectively. Two hundred milligrams of each fraction ( $P$. diospyrifolium, PD and P. gaudichaudianum, PG) was subjected to column chromatography using a Biotage system. The PD resulted in 22 fractions and analyses of fraction 16 and 21 resulted in the purification of the compounds 2 and 1, respectively. The compound 4 was isolated from fraction 12 after PG fractionation in the Biotage. The compound $\mathbf{3}$ was isolated from $P$. cumanense leaves $(1.5 \mathrm{~kg})$ extracted with $95 \%$ of $\mathrm{EtOH}$ in water yielding $0.4 \mathrm{~kg}$ of crude extract (PC). The crude extract was partitioned with $\mathrm{CH}_{2} \mathrm{Cl}_{2}$ (PCDCM), $\mathrm{MeOH}(\mathrm{PCMeOH})$ and $n-\mathrm{BuOH}(\mathrm{PCBuOH})$. The $\mathrm{PCMeOH}$ phase (5 g) was subjected to a column chromatography using gradient of $\mathrm{CH}_{3} \mathrm{Cl}_{3}$ and EtOAc. The $\mathrm{PCMeOH} \_19$ fraction $(2.5 \mathrm{~g})$ was chromatographed on silica gel eluted with $\mathrm{CHCl}_{3}-\mathrm{EtOAc}(90: 10)$ to EtOAc $100 \%$ to give 23 subfractions. Subfraction 6 (PCMeOH_19_sub6, $530 \mathrm{mg})$ was chromatographed by a silica gel column eluted with $\mathrm{CHCl}_{3}-\mathrm{EtOAc}(7: 3)$ to give 6 subfractions. The subfraction obtained from this last separation ( $\mathrm{PCMeOH} \_19 \_s u b 6 \_2,110 \mathrm{mg}$ ) was purified using column chromatography $\mathrm{CHCl}_{3}-$ EtOAc (4:1) to obtain afford $\mathbf{3}(34 \mathrm{mg})$ as a white crystalline solid. 


\subsection{Spectral Data}

Flavokawain A (1). Yellow crystals, UV (MeOH): 364, $252 \mathrm{~nm} .{ }^{1} \mathrm{H}-\mathrm{NMR}\left(\mathrm{CDCl}_{3}\right) \delta 7.57(2 \mathrm{H}$, d, $J=2.0,6.0 \mathrm{~Hz}, \mathrm{H} 2$ and H6), $6.93(2 \mathrm{H}, \mathrm{d}, J=2.0,6.0 \mathrm{~Hz}, \mathrm{H} 3$ and $\mathrm{H} 5), 5.96\left(1 \mathrm{H}, \mathrm{d}, J=2.0 \mathrm{~Hz}, \mathrm{H} 3{ }^{\prime}\right)$, $6.11\left(1 \mathrm{H}, \mathrm{d}, \mathrm{H} 5^{\prime}\right), 7.80(1 \mathrm{H}, \mathrm{s}, \mathrm{H} \alpha$ and $\mathrm{H} \beta), 3.95(3 \mathrm{H}, \mathrm{s}, \mathrm{OMe}-4), 3.84$ (3H, s, OMe-2'), 3.86 (3H, s, OMe-4'). ${ }^{13} \mathrm{C}-\mathrm{NMR}\left(\mathrm{CDCl}_{3}\right) \delta 127.77(\mathrm{C} 1), 130.15$ (C2), 114.38 (C3), 161.38 (C4), 114.38 (C5), 130.15 (C6), 127.82 (C1'), 166.05 (C2'), 91.26 (C3'), 162.48 (C4'), 93.82 (C5'), 168.37 (C6'), 142.54 $(\mathrm{C} \alpha), 125.12(\mathrm{C} \beta), 55.86(\mathrm{OMe}-4), 55.42\left(\mathrm{OMe}-2^{\prime}\right), 55.87\left(\mathrm{OMe}-4^{\prime}\right), 192.63(\mathrm{C}=\mathrm{O})$.

4-Hydroxy-3-(3, 7,11-trimethyldodeca-2,6,10-trienil) benzoic acid (2). Dark yellow solid, UV (MeOH): 330, $254 \mathrm{~nm}$. HR-ESI-MS $m / z:[\mathrm{M}+\mathrm{H}]^{+}$for $\mathrm{C}_{22} \mathrm{H}_{28} \mathrm{O}_{4}=357.2060 ;{ }^{1} \mathrm{H}-\mathrm{NMR}\left(\mathrm{CDCl}_{3}\right) \delta 8.59(1 \mathrm{H}, \mathrm{d}$, $J=2.0 \mathrm{~Hz}, \mathrm{H} 2), 7.03(1 \mathrm{H}, \mathrm{d}, J=10.0 \mathrm{~Hz}, \mathrm{H} 5), 8.16(1 \mathrm{H}, \mathrm{dd}, J=10.0,2.0 \mathrm{~Hz}, \mathrm{H} 6), 6.87$ (1H, s, H3'), 2.37 (2H, m, H4'), 2.04 (2H, m, H5'), 5.17 (1H, m, H6'), 2.37 (2H, m, H8'), 2.04 (2H, m, H9'), 5.09 (1H, m, H10'), 1.65 (3H, s, H12'), 2.26 (3H, s, H13'), 1.57 (3H, s, H15'), 13.49 (1H, s, COOH). ${ }^{13} \mathrm{C}-\mathrm{NMR}\left(\mathrm{CDCl}_{3}\right) \delta 120.31(\mathrm{C} 1), 133.16$ (C2), 119.70 (C3), 167.90 (C4), 119.01 (C5), 137.17 (C6), 195.63 (C1'), 118.80 (C2'), 164.10 (C3'), 42.11 (C4'), 26.81 (C5'), 127.70 (C6'), 136.82 (C7'), 39.79 (C8'), 26.30 (C9'), 124.30 (C10'), 131.57 (C11'), 25.91 (C12'), 20.57 (C13'), 16.28 (C14'), 17.80 $\left(\mathrm{C} 15^{\prime}\right), 170.90(\mathrm{COOH})$.

2',4',6'-Trihydroxydihydrochalcone (3). Crystalline needles, UV $\lambda_{\max }(\mathrm{MeOH}) \mathrm{nm}: 324,285$. IR $v_{\max }$ $(\mathrm{KBr}) \mathrm{cm}^{-1}:$ 3443, 2957, 1649, 1595, 1454, 1395, 1016. HR-ESI-MS $m / z: 259.0980[\mathrm{M}+\mathrm{H}]^{+}$for $\mathrm{C}_{15} \mathrm{H}_{14} \mathrm{O}_{4} .{ }^{1} \mathrm{H}-\mathrm{NMR}\left(\mathrm{CDCl}_{3}\right) \delta 7.27(4 \mathrm{H}, \mathrm{m}, \mathrm{H} 2, \mathrm{H} 3, \mathrm{H} 5$ and $\mathrm{H} 6), 7.17$ (1H, m, H4), 5.85 (2H, s, H3'), $5.85\left(2 \mathrm{H}, \mathrm{s}, \mathrm{H} 55^{\prime}\right), 3.33(2 \mathrm{H}, \mathrm{t}, J=7.8 \mathrm{~Hz}, \mathrm{H \alpha}), 2.98(2 \mathrm{H}, \mathrm{t}, J=7.8 \mathrm{~Hz}, \mathrm{H} \beta) .{ }^{13} \mathrm{C}-\mathrm{NMR}\left(\mathrm{CDCl}_{3}\right)$ $\delta 143.19$ (C1), 129.42 (C2), 129.34 (C3), 126.85 (C4), 129.34 (C5), 129.42 (C6), 105.30 (C1'), 165.81 (C2'), 95.75 (C3'), 166.14 (C4'), 95.75 (C5'), $165.81\left(\mathrm{C}^{\prime}\right), 46.90(\mathrm{C} \alpha), 32.21(\mathrm{C} \beta), 206.04(\mathrm{C}=\mathrm{O})$.

Dihydroflavokawain $C$ (4). Crystalline needles, UV $\lambda_{\max }(\mathrm{MeOH}) 232,285 \mathrm{~nm}$. HR-ESI-MS $m / z$ : $[\mathrm{M}+\mathrm{H}]^{+}=303.1232$ for $\left.\mathrm{C}_{17} \mathrm{H}_{18} \mathrm{O}_{5}\right] .{ }^{1} \mathrm{H}-\mathrm{NMR}\left(\mathrm{CDCl}_{3}\right) \delta 7.09(2 \mathrm{H}, \mathrm{d}, J=8.4 \mathrm{~Hz}, \mathrm{H} 2$ and H6), $6.76(2 \mathrm{H}$, $\mathrm{dd}, J=8.4 \mathrm{~Hz}, \mathrm{H} 3$ and $\mathrm{H} 5), 6.07\left(1 \mathrm{H}, \mathrm{d}, J=8.4 \mathrm{~Hz}, \mathrm{H} 3{ }^{\prime}\right), 5.92\left(1 \mathrm{H}, \mathrm{d}, J=8.4 \mathrm{~Hz}, \mathrm{H} 5^{\prime}\right)$, $3.81\left(3 \mathrm{H}, \mathrm{s}, \mathrm{OCH}_{3}-4^{\prime}\right), 3.83\left(3 \mathrm{H}, \mathrm{s}, \mathrm{OCH}_{3}-5^{\prime}\right), 14.0\left(1 \mathrm{H}, \mathrm{s}, \mathrm{OH}-2^{\prime}\right), 3.27(2 \mathrm{H}, \mathrm{dd}, J=7.4,8.4 \mathrm{~Hz}, \mathrm{H \alpha})$, $2.92(2 \mathrm{H}, \mathrm{dd}, J=7.4,8.4 \mathrm{~Hz}, \mathrm{H} \beta) .{ }^{13} \mathrm{C}-\mathrm{NMR}\left(\mathrm{CDCl}_{3}\right): \delta=133.8(\mathrm{C} 1), 129.5(\mathrm{C} 2), 115.2(\mathrm{C} 3), 153.8$ (C4), 115.2 (C5), 129.5 (C6), 105.7 (C1'), 162.7 (C2'), 90.8 (C3'), 166.0 (C4'), 93.7 (C5'), 167.6 (C6'), $55.6\left(\mathrm{OMe}-2^{\prime}\right), 55.5(\mathrm{OMe}-4$ '), $45.9(\mathrm{C} \alpha), 29.8(\mathrm{C} \beta), 204.7(\mathrm{C}=\mathrm{O})$.

\subsection{Biological Assays}

Assays were performed according to the methodology recommended by the WHO [17,18], and experimental procedures were employed according to accepted principles of animal welfare in experimental science.

Adults and egg masses of B. glabrata (Say, 1818) were obtained from a Belo Horizonte population (MG, Brazil) and reared under laboratory conditions for several years, with fresh lettuce ad libitum for maintenance and a balanced ration during the assay. 
In all assays, both positive and negative controls were used to examine the susceptibility of the organisms under the assay conditions. The commercially available molluscicide niclosamide was used in the positive control group; the negative control group received dechlorinated tap water containing $1 \%$ DMSO.

\subsection{Molluscicidal Activity}

Snails with 10-18 $\mathrm{mm}$ of shell diameter were exposed to $P$. diospyrifolium extract and isolated compounds (Table 1, Supplementary Table S1) at concentrations less than $40 \mathrm{mg} / \mathrm{mL}$ for $24 \mathrm{~h}$ at $24{ }^{\circ} \mathrm{C} \pm 2{ }^{\circ} \mathrm{C}$. After exposure, the snails were washed, observed daily for 7 days, and the death rate was recorded [19]. The $\mathrm{LC}_{90}$ and $\mathrm{LC}_{50}$ values were then determined from the death rate data. Ten animals were used per concentration and experiments were repeated three times.

\subsection{Ovicidal Activity}

Plastic sheets served as the substrate for oviposition, and small circles with one egg mass attached were excised. Five egg masses at the blastula, gastrula, trocophore and veliger stages [20] were exposed to isolated compounds at concentrations less than $20 \mathrm{mg} / \mathrm{mL}$ for $24 \mathrm{~h}$ to determine the $\mathrm{LC}_{90}$ and $\mathrm{LC}_{50}$ values. The number of snail embryos to each concentration is indicated in Supplementary Table S1. Following the exposure, the egg masses were washed with dechlorinated water and Petri dishes containing egg masses were kept within climatic chambers with a controlled temperature $\left(25{ }^{\circ} \mathrm{C} \pm 1{ }^{\circ} \mathrm{C}\right)$. All egg masses were examined daily for 7 days under a stereomicroscope. Embryos were considered as dead whenever disintegrating embryonic forms were noted within the egg and/or at later developmental stages when no heartbeats were detected. Assays were repeated three times with approximately 100 embryos for each concentration.

\subsection{Docking}

The structure of the RXR-like protein (retinoid X receptor) (PDB code: 1XIU) was downloaded from Protein Data Bank [21]. The ligands were drawn using the Marvin Sketch v. 6.1.4 [22], and the three dimensional structures were generated using the software Standardizer v 6.1.4 [23]. Compounds 1-6 were submitted to molecular docking using the Molegro Virtual Docker v. 6.0.1 (MVD) [24,25]. All the water molecules were deleted from enzyme structure, the enzyme and ligands were prepared using default parameter settings on the same software. The active site was the same as that containing the crystallized ligand (retinoic acid). The coordinates of the constraint were: $x=33.87 ; y=38$; $\mathrm{z}=90.28$. Moldock score [GRID] algorithm was used as the score function and the search algorithm was Moldock SE [24]. Rank and re rank were used to select the poses with lowest Moldock energies.

\subsection{Molecular Interaction Fields}

The structures modeled as described above were used as the initial structures to generate molecular descriptors employing the VolSurf $+\mathrm{v}$ 1.0.7 program [26,27]. The descriptors were generated using the following probes: N1 (amide nitrogen—hydrogen bond donor probe), O (carbonyl oxygen — hydrogen 
bond acceptor probe), $\mathrm{OH} 2$ (water probe), and DRY (hydrophobic probe), totalizing 57 descriptors [12]. PCA (Principal Component Analysis) was applied to the investigated set using the same software [24].

\section{Conclusions}

The evaluated compounds were active against Biomphalaria glabrata, and docking simulations described the interaction of all of the compounds in the RXR-like protein's hydrophobic retinoic acid binding pocket. Molecular interaction fields determined the physical-chemical features that explained the highest activity of compounds 2 and 3. Compared to niclosamide $\left(\mathrm{LC}_{50} 0.05 \mu \mathrm{g} / \mathrm{mL}\right)$ [19], the activity of the isolated compounds displayed moderate molluscicidal activity. However, considering the limitations of niclosamide, the compounds investigated in this study are promising molluscicides derived from botanical sources.

\section{Supplementary Materials}

Supplementary materials can be accessed at: http://www.mdpi.com/1420-3049/19/4/5205/s1.

\section{Acknowledgments}

This work was financially supported by São Paulo Research Foundation (FAPESP), Conselho Nacional de Desenvovlimento Científico e Tecnológico (CNPq), Coordenação de Aperfeiçoamento de Pessoal de Nível Superior (CAPES) and Pro-Reitoria de Pesquisas-USP (NAP-PN).

\section{Author Contributions}

Conception the idea and designing the experiments: LFY, LNR, MJK, EN, JVR. Experiments: LFY, LNR, MTS, MR-C, GCF. Analyzed the data: LFY, LNR, MTS, GCF, MR-C, AP. Contributed reagents/materials/analysis tools: LFY, LNR, MJK, EN, MTS, AP. Wrote the paper: LFY, LNR, MJK, EN, MTS, JVR, MR-C.

\section{Conflicts of Interest}

The authors declare no conflict of interest.

\section{References}

1. Prevention and Control of Schistosomiasis and Soil-transmitted Helminthiasis: Report of a WHO Expert Committee; Technical report series, 912; World Health Organization: Geneva, Switzerland, 2002.

2. Chitsulo, L.; Engels, D.; Montresor, A.; Savioli, L. The global status of schistosomiasis and its control. Acta Trop. 2000, 77, 41-51.

3. World Health Organization. Weekly epidemiological record. WHO 2011, 9, 73-80.

4. Lardans, V.; Dissous, C. Snail control strategies for reduction of schistosomiasis transmission. Parasitol. Today 1998, 14, 413-417. 
5. Second Report of the WHO Expert Committee; 830; World Health Organization: Geneva, Switzerland, 1993; pp. 1-86.

6. Pointier, J.P.; Giboda, M. The case for biological control of snail intermediate hosts of Schistosoma mansoni. Parasitol. Today 1999, 15, 395-397.

7. Hostettmann, K.; Potterat, O. Strategy for the isolation and analysis of antifungal, molluscicidal, and larvicidal agents from tropical plants. In Phytochemicals for Pest Control; ACS Symposium Series 658; American Chemical Society: Washington, DC, USA, 1997; pp. 14-26.

8. Rapado, L.N.; Nakano, E.; Ohlweiler, F.P.; Kato, M.J.; Yamaguchi, L.F.; Pereira, C.A.B.; Kawano, T. Molluscicidal and ovicidal activities of plant extracts of the Piperaceae on Biomphalaria glabrata (Say, 1818). J. Helminthol. 2010, 85, 66-72.

9. De Groot, A.; de Rosny, E.; Juillan-Binard, C.; Ferrer, J.L.; Laudet, V.; Pierce, R.J.; Pebay-Peyroula, E.; Fontecilla-Camps, J.C.; Borel, F. Crystal structure of a novel tetrameric complex of agonist-bound ligand-binding domain of Biomphalaria glabrata retinoid $\mathrm{X}$ receptor. J. Mol. Biol. 2005, 354, 841-853.

10. Robinson-Rechavi, M.; Garcia, H.E.; Laudet, V. The nuclear receptor superfamily. J. Cell Sci. 2003, 116, 585-586.

11. Fang, H.; Tong, W.D.; Welsh, W.J.; Sheehan, D.M. QSAR models in receptor-mediated effects: The nuclear receptor superfamily. J. Mol. Struc-Theochem. 2003, 622, 113-125.

12. Cruciani, G.; Crivori, P.; Carrupt, P.A.; Testa, B. Molecular fields in quantitative structurepermeation relationships: The VolSurf approach. J. Mol. Struc-Theochem. 2000, 503, 17-30.

13. Dharmaratne, H.R.W.; Nanayakkara, N.P.; Khan, I.A. Kavalactones from Piper methysticum, and their ${ }^{13} \mathrm{C}$ NMR spectroscopic analyses. Phytochemistry 2002, 59, 429-433.

14. Seeram, N.P.; Jacobs, H.; McLean, S.; Reynolds, W.F. Prenylated hydroxybenzoic acid derivatives from Piper murrayanum. Phytochemistry 1996, 43, 863-865.

15. Mustafa, K.; Kjaergaard, H.G.; Perry, N.B.; Weavers, R.T. Hydrogen-bonded rotamers of 2',4',6'-trihydroxy-3-formyldihydrochalcone, an intermediate in the synthesis of a dihydrochalcone from Leptospermum recurvum. Tetrahedron 2003, 59, 6113-6120.

16. Dutta, C.P.; Roy, L.P.K.; Chatterjee, A. Studies on the genus Piper. 5. Chemical investigation of Piper methysticum Forst (Piperaceae). Structure and synthesis of flavokawain C. J. Indian Chem. Soc. 1976, 53, 1194-1197.

17. World Health Organization. Molluscicide screening and evaluation. Bull. World Health Organ. 1965, 33, 567-581.

18. Second Report of the WHO Expert Committee; 745; World Health Organization: Geneva, Switzerland, 1983; p. 11.

19. Rapado, L.N.; Pinheiro, A.S.; Lopes, P.O.M.V.; Fokoue, H.H.; Scotti, M.T.; Marques, J.V.; Ohlweiler, F.P.; Borrely, S.I.; Pereira, C.A.B.; Kato, M.J.; et al. Schistosomiasis control using piplartine against Biomphalaria glabrata at different developmental stages. PLoS Negl. Trop. Dis. 2013, 7, e2251.

20. Camey, T.; Verdonk, N.H. The early development of the snail Biomphalaria glabrata (Say) and the origin of the head organs. Neth. J. Zool. 1970, 20, 93-121.

21. Protein Data Bank. Available online: http://www.rcsb.org/pdb/home/home.do/ (accessed on 25 January 2014). 
22. Marvin Sketch, v. 6.1.4.; Chemaxon: Budapest, Hungary, 2014.

23. Standardizer, v. 6.1.4.; Chemaxon: Budapest, Hungary, 2014.

24. Thomsen, R.; Christensen, M.H. MolDock: A new technique for high-accuracy molecular docking. J. Med. Chem. 2006, 49, 3315-3321.

25. Docker, v.6.0.1.; CLC Bio: Cambridge, MA, USA, 2014.

26. Wold, P.; Esbensen, K.; Geladi, P. Principal Component Analysis. Chemometr. Intell. Lab. 1987, 2, 37-52.

27. VolSurf+, v. 1.0.7.; Molecular Discovery: Middlesex, UK, 2014.

Sample Availability: Not available.

(C) 2014 by the authors; licensee MDPI, Basel, Switzerland. This article is an open access article distributed under the terms and conditions of the Creative Commons Attribution license (http://creativecommons.org/licenses/by/3.0/). 